\title{
A Isometricidade do Ligamento Cruzado Posterior
}

\author{
Isometry of the Posterior Cruciate Ligament
}

Alexandre E. V. Kokron'; Arnaldo J. Hernandez ${ }^{2}$; Gillberto L. Camanho3; Marco M. Amatuzzi ${ }^{4}$

\section{RESUMO}

Trabalho de revisão bibliográfica referente à isometricidade do ligamento cruzado posterior. São avaliados doze artigos que estudam a isometricidade do ligamento, constatando que a maioria destes é concorde com a maior importância da inserção femoral na isometricidade e que existe uma linha ou área mais isométrica na inserção femoral, aproximadamente perpendicular ao teto da fossa intercondilar, localizada de 10 a 14mm da abertura anterior desta fossa.

Descritores: Biomecânica - Ligamento Cruzado Posterior/Lesões - Ligamento Cruzado Posterior/ Cirurgia

\section{INTRODUÇÃO}

O conhecimento da isometricidade do ligamento cruzado posterior (LCP) é considerado fundamental para se reconstruir o LCP, e é estudada por vários autores com diferentes modelos experimentais, tais como o uso de fio inextensível conectando os pontos ou através de cálculo trigonométrico $(3,4,5,6,7,8,9,11,12,13,14,15$, 16).

Neste estudo objetivamos resumir as informações obtidas na literatura referentes à isometricidade do ligamento cruzado posterior.

Existe confusão na literatura para orientação das direções dentro da fossa intercondilar decorrente do uso de duas nomenclaturas, a anatômica, que denomina as direções com o joelho posicionado em extensão, e a cirúrgica, cuja orientação

\section{SUMMARY}

The authors review 12 studies about posterior cruciate ligament isometry. The authors conclude that most studies agree that femoral insertion of the ligament is more important for isometry, and that there is a most isometric line or area inside the femoral insertion, perpendicular to the roof of the intercondilar fossa, approximately 10 to $14 \mathrm{~mm}$ from its anterior opening.

Key words: Biomechanics - Posterior Cruciate Ligament/ Injuries Posterior Cruciate Ligament/ Surgery

\section{INTRODUCTION}

To reconstruct the posterior cruciate ligament (LCP) it is fundamental to know its isometry. The LCP isometry was studied by several authors using different experimental models, as unextensible wire connecting the points or trigonometric calculus, (Bach et al. ${ }^{3}$, Bomberg et al. ${ }^{4}$, Covey et al. ${ }^{5}$, Friederich and O'Brien ${ }^{6}$, Grood et al. ${ }^{8}$, Juergensen et al. ${ }^{9}$, Kurosawa et al. ${ }^{11}$, Odensten and Gillquist ${ }^{12}$, Ogata and McCarthy ${ }^{13}$, Ortiz et al. ${ }^{14}$, Sidles et al. ${ }^{15}$, Trus et al. $\left.{ }^{16}\right)$.

The aim of this study was to summarize information from the literature as concerns isometry of the posterior cruciate ligament.

The literature is confuse as concerns guiding directions inside the intercondylar fossa, since two nomenclatures are used: the anatomical, which considers directions with the extended knee, and the surgical,
Trabalho realizado no Instituto de Ortopedia e Traumatologia do Hospital das Clínicas da Faculdade de Medicina da Universidade de São Paulo.

1 Doutor em Ortopedia

2 Doutor do IOT - HC - FMUSP

3 Professor Livre Docente do IOT

4 Professor Titular e Chefe do Departamento de Ortopedia e Traumatologia da Faculdade de

Medicina da Universidade de São Paulo.
Orthopedics and Traumatology Institute, "Hospital das Clínicas", University of São Paulo College of Medicine

1 Doutor em Ortopedia

2 Doutor do IOT - HC - FMUSP

3 Professor Livre Docente do IOT

4 Professor Titular e Chefe do Departamento de Ortopedia e Traumatologia da Faculdade de Medicina da Universidade de São Paulo. 
dentro da fossa intercondilar baseia-se no joelho fletido a 90 graus (1). Para evitar tal confusão, a Sociedade Européia de Medicina Esportiva, Cirurgia do Joelho e Artroscopia ("European Society of Sports Medicine, Knee Surgery and Arthroscopy") orienta que a terminologia utilizada para o posicionamento dentro da fossa intercondilar seja sempre a anatômica ${ }^{(1)}$. Como no plano sagital o teto da fossa intercondilar é oblíquo às direções ântero-posterior e proximal-distal, referir-se a um ponto como anterior a outro ao longo deste teto implica automaticamente em dizer que o primeiro ponto é distal ao segundo, e a recíproca também é verdadeira; já na afirmação de que um ponto é mais posterior ao longo do teto da fossa intercondilar está implícito que o ponto também é mais proximal $^{(1)}$.

Dos estudos que comparam a variação da isometricidade causada por modificações da localização dos pontos no fêmur e na tíbia, os resultados são uniformes de que modificações na tíbia causam pequenas alterações na isometricidade, enquanto que mudanças da localização de pontos no fêmur podem causar grandes variações da isometricidade $(3,4,6,8,9,15,16)$.

Existem controvérsias na literatura em relação à área mais isométrica do LCP no fêmur. A maioria dos estudos observa que modificações ao longo do teto da fossa intercondilar para anterior (distal) ou para posterior (proximal) causa variações importantes na isometricidade das fibras e que modificações numa direção perpendicular ao teto ocasionam pequenas variações na isometricidade $(4,6,8,13,15,16)$. Assim sendo, alguns autores definem dentro da inserção anatômica do LCP, uma linha ou área isométrica, aproximadamente perpendicular ao teto da fossa, que divide sua inserção em duas áreas não isométricas; a área isométrica possui uma largura aproximada de $3 \mathrm{~mm}$, e as fibras nela inseridas apresentam comportamento isométrico ou quase isométrico $(6,8,15$, 16). A maioria das fibras do LCP estão inseridas na área não isométrica distal (anterior) à linha e se alongam de 4 a $8 \mathrm{~mm}$ com a flexão do joelho, relaxando-se em extensão; as fibras inseridas na área não isométrica proximal (posterior) se alongam em extensão e relaxam em flexão $(3,4,5,6,8,9,11,12,13,15,16)$.

A localização desta linha isométrica na inserção femoral do LCP é descrita por alguns autores através da distância ao longo do teto da fossa intercondilar à junção cartilagem-osso na abertura anterior da fossa, medindo-a em milímetros, enquanto outros preferem utilizar a regra de um terço da profundidade do teto ou usar a inserção do ligamento como referência $(3,4,5,6,8,9,12,13,14,15,16)$. Quando avaliada em números absolutos, a linha isométrica se localiza ao longo do teto da fossa intercondilar, a uma distância de $13 \mathrm{~mm}$ segundo SIDLES et al. ${ }^{15} \mathrm{e} 11 \mathrm{~mm}$ segundo GROOD et al. ${ }^{8}$. A regra de um terço da profundidade, utilizada por OGATA e MCCARTHY ${ }^{13}$ e por TRUS et al. ${ }^{16}$, consiste na mensuração da distância entre as aberturas anterior e posterior da fossa intercondilar, cujo valor é dividido por três; o resultado desta divisão é a medida da profundidade da linha isométrica a partir da junção cartilagem osso da abertura anterior (figura 1). O resultado deste cálculo segundo as comunicações de OGATA e MCCARTHY ${ }^{13} \mathrm{e}$ TRUS et al. ${ }^{16}$ é de $10 \mathrm{~mm}$ e $11 \mathrm{~mm}$, respectivamente. Em estudo based on a 90 degrees bent knee (Amis et al. ${ }^{1}$ ). To avoid this, the European Society of Sports Medicine, Knee Surgery and Arthroscopy suggests that the anatomical terminology is used concerning positioning inside the intercondylar fossa (Amis et al. ${ }^{1}$ ). Considering that in the sagittal plane the roof of the intercondylar fossa is oblique in relation to the anterior-posterior and proximal-distal directions, if along this roof a point is anterior to another it is automatically distal to the latter; however, when a point is said to be in a more posterior position along the roof of the intercondylar fossa, that point is also more proximal (Amis et al. ${ }^{1}$ ).

Results from studies which compare variation in isometry caused by modification in the localization of femur and tibia points show uniformity since modifications in the tibia cause small alterations in isometry, while changes in the localization of points in the femur can cause large variations in isometry (Bach et al. ${ }^{3}$, Bomberg et al. ${ }^{4}$, Friederich and O'Brien ${ }^{6}$, Grood et al. ${ }^{8}$, Juergensen et al. ${ }^{9}$, Sidles et al. ${ }^{15}$, Trus et al. $\left.{ }^{16}\right)$.

There are controversies in the literature concerning the PCL most isometric area in the femur. Most of the studies observe that modifications along the roof of the intercondylar fossa to the anterior (distal) or posterior (proximal) positions cause important variations in the fibers isometry and also that modifications in a direction perpendicular to the roof cause small variations in isometry (Bomberg et al. ${ }^{4}$, Friederich and O'Brien ${ }^{6}$, Grood et al. ${ }^{8}$, Ogata and McCarthy ${ }^{13}$, Sidles et al. ${ }^{15}$, Trus et al. $\left.{ }^{16}\right)$. Accordingly, inside the anatomical insertion of the PCL some authors define an isometric line or area, approximately perpendicular to the roof of the fossa, dividing its insertion in two non-isometric areas; the isometric area is about $3 \mathrm{~mm}$ wide, and the inserted fibers present an isometric or almost isometric behavior (Friederich and O'Brien ${ }^{6}$, Grood et al. ${ }^{8}$, Sidles et al. ${ }^{15}$, Trus et al. ${ }^{18}$ ). Most of the PCL fibers are inserted in the distal (anterior) non-isometric area and are lengthened 4 to $8 \mathrm{~mm}$ with a bent knee, loosening in extension; the fibers inserted in the proximal (posterior) non-isometric area lenghten in extension and loose in flexure (Back et al. ${ }^{3}$, Bomberg et al. ${ }^{4}$, Covey et al. ${ }^{5}$, Friederich and O'Brien ${ }^{6}$, Grood et al. ${ }^{8}$, Juergensen et al. ${ }^{9}$, Kurosawa et al. ${ }^{11}$, Odensten and Gillquist ${ }^{12}$, Ogata and McCarthy ${ }^{13}$, Sidles et al. ${ }^{15}$, Trus et al. ${ }^{16}$ ).

Some authors describe the localization of this isometric line in the PCL femoral insertion as the distance in milimeters along the intercondylar fossa roof until the cartilage-bone junction in the anterior opening of the fossa, while others prefer to use the third of the roof depth rule or use the ligament insertion as reference (Back et al. ${ }^{3}$, Bomberg et al. ${ }^{4}$, Covey et al. ${ }^{5}$, Friederich and O'Brien ${ }^{6}$, Grood et al. ${ }^{8}$, Juergensen et al. ${ }^{9}$, Odensten and Gillquist ${ }^{12}$, Ogata and McCarthy ${ }^{13}$. Ortiz et al. ${ }^{14}$, Sidles et al. ${ }^{15}$, Trus et al. ${ }^{16}$ ). When expressed in absolute numbers, the isometric line is located along the intercondylar fossa roof at $13 \mathrm{~mm}$ according to Sidles et al. ${ }^{15}$ and $11 \mathrm{~mm}$ according to Grood et al. ${ }^{8}$. The third of the depth rule, used by Ogata and McCarthy ${ }^{13}$ and by Trus et al. ${ }^{16}$, consists of measuring the distance between the anterior and posterior opening of the intercondylar fossa, and dividing it by three; the result of this division is the isometric line depth from the cartilage-bone junction of the anterior opening (figure 1). According to Ogata and McCarthy ${ }^{13}$ and Trus et al. ${ }^{16}$, the results were $10 \mathrm{~mm}$ 
nacional, KOKRON ${ }^{10}$ nota que a profundidade da fossa intercondilar é de $31,6 \mathrm{~mm}$ na média de 14 joelhos (mínimo de 29mm e máximo de $34 \mathrm{~mm}$ ). Portanto o terço deste valor corresponde a 10 ou $11 \mathrm{~mm}$, valores semelhantes aos descritos por OGATA e MCCARTHY ${ }^{13} \mathrm{e}$ TRUS et al. ${ }^{16}$.

Outros autores preferem utilizar a inserção anatômica femoral como referência para o local do ponto isométrico, tal qual descrito por COVEY et al. ${ }^{5}$ e por FRIEDERICH e O'BRIEN ${ }^{6}$. Não consideramos adequado utilizar esta referência em joelhos com lesão crônica do ligamento, aonde este parâmetro pode estar alterado.

A área isométrica da inserção femoral do LCP pode variar com muitos fatores, tais como a direção de força aplicada na tíbia, presença ou não de afastamento articular pelo peso da perna e pé, a presença de contração muscular, e até pela integridade ou não do LCP $5,8,11,14$. A influência da contração muscular na isometricidade do LCP é inicialmente relatada por KUROSAWA et al. ${ }^{11} \mathrm{em} 1991$, que constata que a aplicação de uma força na patela, simulando uma contração do músculo quadríceps da coxa, diminui o comprimento das fibras do LCP em diversos ângulos de flexão do joelho em relação à avaliação sem aplicação de força. No estudo de ORTIZ et al. ${ }^{14}$, simulando em laboratório algumas situações de contração muscular que correspondem a atividades de vida diária de uma pessoa, a localização do ponto isométrico do LCP se modifica tanto que fica fora da inserção femoral do ligamento. A própria ausência do LCP acarreta alterações na isometricidade, pois a ausência do restritor primário do deslocamento posterior da tíbia permite que ela se encontre em posição mais posterior durante todo o arco de movimento do joelho, análogo ao que ocorre com a isometricidade do LCA quando de sua ausência ${ }^{2,5,7}$.

Nossa preferência para localizar a linha isométrica no fêmur consiste na utilização da regra do terço, pois esta leva em consideração o tamanho do joelho, embora cientes de que o resultado obtido por este valor é muitas vezes coincidente com os resultados de GROOD et al. ${ }^{8}$.

A localização do centro do túnel tibial altera pouco a isometricidade do enxerto, desde que esteja dentro da inserção anatômica do ligamento.

A controvérsia referente ao uso de túnel femoral isométrico ou de túnel femoral não isométrico (anterior à linha isométrica) será descrita em outro artigo de revisão. and $11 \mathrm{~mm}$, respectively. In a national study, Kokron ${ }^{10}$ observes that the intercondylar fossa depth is $31.6 \mathrm{~mm}$ averaging 14 knees (minimum $29 \mathrm{~mm}$ and maximum $34 \mathrm{~mm}$ ). Thus, one third of these numbers corresponds to 10 or $11 \mathrm{~mm}$, as those described by Ogata and McCarthy ${ }^{13}$ and Trus et al. ${ }^{16}$.

Other authors prefer to use as reference the femoral anatomical insertion concerning the site of the isometric point, as described by Covey et al. ${ }^{5}$ and Friederich and O'Brien ${ }^{6}$. We do not consider this reference adequate for knees with chronic ligament lesion when this parameter can show alterations.

The isometric area of the PCL femoral insertion can vary due to several factors: direction of the force applied to the tibia, presence or absence of articular spacing due to weight of the leg or foot, presence of muscular contraction, and even integrity or lack of integrity of the PCL (Covey et al. ${ }^{5}$, Grood et al. ${ }^{8}$, Kurosawa et al. ${ }^{11}$, Ortiz et al. ${ }^{14}$ ). The influence of muscular contraction on the PCL isometry was initially reported by Kurosawa et al. ${ }^{11}$ in 1991, who observed that the application of a force on the patella simulating contraction of the quadriceps lessens the lenght of the PCL fibers in several angles of knee flexure as compared to the evaluation without the application of force. In the Ortiz et al. ${ }^{14}$ study, simulating in laboratory situations of muscular contraction corresponding to daily life activities, the localization of the PCL isometric point is so much modified that it remains outside the ligament femoral insertion. The very absence of the PCL produces alterations in isometry, since the absence of primary restriction on the posterior displacement of the tibia allows it to stay in a more posterior position during all the arch of movement of the knee, similarly to what occurs with isometry when the ACL is absent (Amis and Jakob'2, Covey et al. ${ }^{5}$, Furia et al. ${ }^{7}$ ).

We prefer to locate the femur isometric line using the rule of the third, since it considers knee size; we are aware that the results using this value are consistent with Grood et al. ${ }^{8}$ 's results. The localization of the center in the tibia tunnel somewhat alters the graft isometry, since it is inside the ligament anatomical insertion.

The controversy concerning the use of the femoral isometric tunnel or the femoral nonisometric tunnel (anterior to the isometric line) will be described in another review.
Fig. 1 Relação da linha isométrica da inserção femoral do LCP, aqui representada por uma linha tracejada, com o teto da fossa intercondilar, cuja profundidade é mensurada pela distância entre os pontos $\mathrm{O}$ e l; a linha ou área isométrica, localiza-se a um terço da profundidade da fossa a partir do ponto segundo OGATA e MCCARTHY13 e TRUS et al. ${ }^{16}$.
Fig. 1 Relationship between the isometric line of the PCL femoral insertion, represented by a hatched line, with the intercondylar fossa roof, whose depth is determined by the distance between $\mathrm{O}$ and I; the isometric line or area is located at one third depth of the fossa, from the point, according to Ogata and McCarthy ${ }^{13}$ and Trus et al. ${ }^{16}$. 


\section{REFERÊNCIAS}

1. AMIS, A.A., BEYNNON, B., BLANKEVOORT, L., CHAMBAT, P., CHRISTEL, P., DURSELEN, L., FRIEDERICH N., GROOD, E., HERTEL, P., JAKOB, R.P., MULLER, W., O'BRIEN, M. \& O'CONNOR, J.: Proceedings of the ESSKA scientific workshop on reconstruction of the anterior and posterior cruciate ligaments. Knee Surg. Sports Traumatol. Arthrosc., 2:124-32, 1994.

2. AMIS, A.A. \& JAKOB, R.P.: Anterior cruciate ligament graft positioning, tensioning and twisting. Knee Surg. Sports Traumatol. Arthrosc., 6:212, 1998. Supplement 1 .

3. BACH B.R., DALUGA, D.J., MIKOSZ, R., ANDRIACCHI, T.P. \& SEIDL, R.: Force displacement characteristics of the posterior cruciate ligament. Am. J. Sports Med., 20: 67-72, 1992.

4. BOMBERG, B.C., ACKER, J.H., BOYLE, J. \& ZARINS, B.: The effect of posterior ligament loss and reconstruction on the knee. Am. J. Knee Surg., 3:85-96, 1990.

5. COVEY, D.C., SAPEGA, A.A. \& SHERMAN, G.M.: Testing for isometry during reconstruction of the posterior cruciate ligament: anatomic and biomechanical considerations. Am. J. Sports Med., 24:740-6, 1996.

6. FRIEDERICH, N.F. \& O'BRIEN, W.R.: Functional anatomy of the cruciate ligaments; in: Jakob, R.P. \& Stäubli H.-U., ed. The knee and the cruciate ligaments. Berlin, Springer-Verlag, 1992. p. 78-91

7. FURIA, J.P., LINTNER, D.M., SAIZ, P., KOHL, H.W. \& NOBLE, P.: Isometry measurements in the knee with the anterior cruciate ligament intact, sectioned, and reconstructed. Am. J. Sports Med., 25:34652, 1997.

8. GROOD, E.S., HEFZY, M.S. \& LINDENFIELD, T.N.: Factors affecting the region of most isometric femoral attachments. Am. J. Sports Med., 17: 197-207, 1989.
9. JUERGENSEN, K., EDWARDS, J.C. \& JAKOB, R.P.: Positioning of the posterior cruciate ligament. Knee Surg. Sports Traumatol. Arthrosc., 2:133-7, 1994

10. KOKRON, A.E.V.: Avaliação da estabilidade da reconstrução na lesão isolada do ligamento cruzado posterior com um e dois feixes de enxerto. Estudo experimental com tendão do músculo quadríceps da coxa e com tendões dos músculos semitendíneo e grácil. São Paulo, 2000. Tese (Doutorado) - Faculdade de Medicina, Universidade de São Paulo.

11. KUROSAWA, H., YAMAKOSHI, K-I., YASUDA, K. \& SASAKI, T.: Simultaneous measurement of changes in length of the cruciate ligaments during knee motion. Clin. Orthop., 265:233-9, 1991.

12. ODENSTEN, M. \& GILLQUIST, J.: Reconstruction of the posterior cruciate ligament using a new drill-guide. Knee Surg. Sports Traumatol. Arthrosc., 1, 39-43, 1993

13. OGATA, K. \& MCCARTHY, J.Á.: Measurements of length and tension patterns during reconstruction of the posterior cruciate ligament. Am. J. Sports Med., 20:351-5, 1992

14. ORTIZ, G.J., SCHMOTZER, H., BERNBECK, J., GRAHAM, S., TIBONE, J.E. \& VANGSNESS, C.T., JR.: Isometry of the posterior cruciate ligament. Am. J. Sports Med., 26: 663-8, 1998.

15. SIDLES, J.A., LARSON, R.V. \& GARBINI, J.L.: Ligament length relationships the moving knee. J. Orthop Res., 6:593-610, 1988.

16. TRUS, P., PETERMANN, J. \& GOTZEN, L.: Posterior cruciate ligament $(P C L)$ reconstruction - an in vitro study of isometry. Part I. Tests using a string linkage model. Knee Surg. Sports Traumatol. Arthrosc., 2:1003, 1994. 